\title{
MEMBANGUN TRUST TERHADAP PELANGGAN TUKANG KIRIDIT
}

\author{
Abdul Aziz \\ Fakultas Ilmu Komunikasi, Universitas Islam Riau
}

\begin{abstract}
ABSTRAK
Profesi tukang kiridit keliling yang menjual berbagai peralatan rumah tangga, merupakan profesi khas orang Tasikmalaya. Ciri khas usaha kiridit ini di antaranya; tidak menggunakan jaminan, tidak mengharuskan uang muka, dan pembayaran angsuran sangat fleksibel bisa dilakukan secara harian, mingguan, dan bulanan. Dalam bisnis seperti ini, trust merupakan faktor utama yang dijadikan pegangan tukang kiridit. Realitas demikian menyebabkan tidak sedikit pelanggan kiridit yang mengkhianati dan lari dari kewajibannya menyelesaikan pembayaran angsuran. Tujuan penelitian adalah untuk memahami dan menganalisis: latar belakang dan proses menjadi tukang kiridit; persepsi tukang kiridit terhadap diri dan profesinya; proses komunikasi interpersonal tukang kiridit dengan pelanggannya; dan konstruksi sosial tukang kiridit tentang faktor trust terhadap pelanggannya. Untuk mencapai tujuan tersebut, penelitian menggunakan paradigma konstruktivisme dan metode penelitian kualitatif, dengan subjek penelitian terdiri dari 13 orang tukang kiridit yang dipilih secara purposif. Pendekatan yang dipakai dalam penelitian ini adalah interaksionisme simbolik dan teori konstruksi sosial atas realitas, dan untuk mengumpulkan data digunakan wawancara mendalam, observasi partisipan dan studi dokumentasi. Temuan penelitian di antaranya: proses menjadi tukang kiridit dikategorikan menjadi tukang kiridit milu dulur dan milu batur. Pandangan tukang kiridit terhadap diri dan profesinya umumnya sangat positif. Proses komunikasi interpersonal tukang kiridit dengan pelanggannya banyak diwarnai dengan pengelolaan kesan baik secara verbal dan nonverbal. Konstruksi trust terhadap pelanggan banyak didasarkan pada perilaku komunikasi nonverbal pelanggan dan kondisi ekonomi pelanggan.
\end{abstract}

Kata-kata kunci: trust, tukang kiridit, komunikasi interpersonal, interaksionisme simbolik, konstruksi sosial.

\section{BUILDING TRUST TOWARDS CUSTOMERS OF “TUKANG KIRIDIT"}

\begin{abstract}
The profession of 'Top of Form Tukang kiridit'which sells various household appliances, is typical profession of Tasikmalaya's people. Characteristics of these business (kiridit); not use the warranty, does not require a down payment, and installment payments can be made daily, weekly, and monthly. In a business like this, trust is the main factor that builders hold by 'tukang kiridit'. Thus causing no little reality 'kiridit' customers who betrayed and ran away from completing the installment to bligation. The research objective is to understand and analyze: the background and process of becoming a 'tukang kiridit'; 'tukang kiridit' perception of self and the profession; the process of interpersonal communication of 'tukang kiridit' with their customers, and the 'tukang kiridit'social construction of trust factors on customers. To achieve these objectives, the research uses a constructivism paradigm and qualitative research method, the study subjects consisted of 13 'tukang kiridit' purposively selected. The approach used in this study is symbolic interaction is mand the theory of social construction of reality, and to collect the data used in - depth interviews, participant observation and documentation study. The study's findings include: the process of being categorized as a 'tukang kiridit Milu Dulur' and 'tukang kiridit Milu Batur'. 'Tukang kiridit'view of their self and the profession generally very positive. The process of interpersonal communication with its customers many done with impression management both verbally and nonverbally. A lot of Construction of trust to customers based on nonverbal communication behavior of the customer and the customer economy condition.
\end{abstract}

Keywords: trust, tukang kiridit, interpersonal communication, symbolic interactionism, social construction.

Korespondensi: Dr. Abdul Aziz, M.Si., Fakultas Ilmu Komunikasi, Universitas Islam Riau, Jl. Kaharuddin Nasution No. 13 Pekanbaru, Email: abazuban@gmail.com 


\section{PENDAHULUAN}

Profesi sebagai tukang kiridit sudah banyak dijalankan oleh masyarakat Tasikmalaya secara turun temurun selama puluhan tahun. Seiring dengan pertumbuhan penduduk dan kebutuhan rumah tangga yang kian kompleks, pada akhirnya profesi sebagai tukang kiridit tidak lagi dianggap sebagai pekerjaan sampingan, tetapi justru menjadi mata pencaharian utama dan dianggap lebih menjanjikan daripada mengandalkan penghasilan dari sawah atau ladang. Bahkan tidak sedikit para petani ini yang berani meninggalkan pekerjaan taninya dan beralih secara total menjadi tukang kiridit. Begitu juga kota yang menjadi sasaran mereka tidak lagi terbatas pada kota-kota di Jawa Barat, atau kota yang ada di Pulau Jawa, tetapi sampai merambah kota-kota yang ada di luar Pulau Jawa seperti di Sumatera, Kalimantan, Sulawesi, bahkan sampai ke Papua.

Kiridit atau kredit berasal dari bahasa Latin 'credere' artinya percaya. Karena itulah kredit dalam arti luas adalah kepercayaan. Maksud dari percaya di sini, adalah adanya kepercayaan atau keyakinan dari si pemberi kiridit (tukang kiridit) kepada si penerima kiridit (pelanggan/pembeli) bahwa barang yang dikiriditkan pasti akan dibayar sesuai dengan perjanjian. Bagi si penerima kiridit (pembeli) sendiri, kepercayaan berimplikasi pada kewajiban mereka untuk membayar cicilan selama jangka waktu tertentu.

Untuk membangun komunikasi yang efektif supaya bisa bekerja sama, terlebih di dalam konteks hubungan bisnis, seseorang harus mampu membangun tingkat kepercayaan (trust) yang tinggi, atau sering disebut dengan mutual trust. Membangun suatu kepercayaan akan lebih kompleks lagi manakala berhadapan dengan seseorang yang memiliki banyak perbedaan dengan kita seperti berbeda latar belakang sosial, budaya, pendidikan, suku (etnik), dan agama, apalagi kepentingan.

Kepercayaan (trust) dalam transaksi bisnis kiridit merupakan hal yang sangat krusial. Seperti telah diuraikan sebelumnya, kredit sendiri berarti kepercayaan. Kepercayaan dalam transaksi tukang kiridit semakin penting lagi karena dalam bisnis ini

tidak ada istilah jaminan yang dapat dipegang oleh tukang kiridit. Bahkan pembayaran uang muka (DP) pun tidak menjadi suatu keharu- san kecuali untuk barang-barang tertentu yang nilainya tinggi. Oleh karena itu adanya trust terhadap pelanggan merupakan modal dasar dalam bisnis seperti ini. Di sisi lain, hampir semua tukang kiridit pernah mengalami dikelabui pelanggannya. Lalu bagaimanakah tukang kiridit mengkostruksi trust terhadap pelanggan ini untuk mengantisipasi hal-hal yang tidak diinginkan terjadi di kemudian hari dan supaya pengalaman pahit tidak terulang kembali? Inilah fokus permasalahan yang dibahas dalam tulisan ini.

Pada dasarnya penelitian ini bermaksud untuk mengetahui, memahami, dan menganalisis cara tukang kiridit mengkonstruksi trust terhadap pelanggannya melalui pendekatan teori interaksi simbolik dan teori konstruksi sosial atas realitas. Pendekatan interaksi simbolik merupakan pendekatan utama dalam tradisi fenomenologi yang menganggap kesadaran manusia dan makna subjektif sebagai titik fokus dalam memahami tindakan sosial. Menurut LaRossa dan Reitzes (dalam West dan Turner, 2008: 96-100), asumsi utama yang melandasi teori interaksi simbolik adalah: (1) pentingnya makna bagi perilaku manusia; (2) pentingnya konsep diri; dan (3) hubungan antara individu dan masyarakat. Berdasarkan hal tersebut, maka tujuan penelitian ini dapat dijabarkan ke dalam empat pernyataan berikut, yaitu untuk memahami dan menganalisis: (a) Latar belakang dan proses menjadi tukang kiridit; (b) Persepsi tukang kiridit terhadap diri dan profesinya sendiri; (c) Proses komunikasi interpersonal tukang kiridit dengan pelanggannya; dan (d) Konstruksi sosial tentang faktor trust terhadap pelanggan kiridit.

Sesuai dengan tujuan yang ingin dicapai seperti telah dijelaskan di atas, maka dalam penelitian ini dirumuskan empat pernyatan permasalahan yang menyangkut hal berikut: (1) Latar belakang dan proses informan menjadi seorang tukang kiridit: (2) Persepsi tukang kiridit terhadap diri dan profesinya; (3) Proses komunikasi interpersonal tukang kiridit dengan pelanggannya; (4) Konstruksi sosial tentang faktor trust terhadap pelanggan kiridit.

\section{METODE PENELITIAN}

Metode penelitian yang dipilih adalah metode kualitatif yang pada umumnya bertujuan untuk mendapatkan pemahaman tentang kenyataan 
melalui proses berpikir induktif. Peneliti terlibat dalam situasi dan setting fenomena yang diteliti. Tujuan penelitian bukan untuk memperoleh pengetahuan yang bersifat nomothetis atau nomotetik (hukum-hukum yang dapat digeneralisasikan), tetapi mencari dan mengembangkan pengetahuan idiografis yaitu berupa penjelasan kasus-kasus (Rakhmat, 1999: 215).

Sumber data yang menjadi subjek utama dalam penelitian ini adalah tukang kiridit migran yang berasal dari Kabupaten Tasikmalaya Jawa Barat yang berada di Kota Pekanbaru dan tergabung dalam paguyuban 'binangkit'. Selain tukang kiridit, subyek penelitian juga ditambah dari pihak pelanggan yang dipilih mewakili etnik pelanggan yang ada di Kota Pekanbaru dan bersedia memberikan informasi dan pengalamannya selama menjadi pelanggan dan berinteraksi dengan tukang kiridit.

Cara penentuan sumber data yang digunakan disini adalah melalui purposive sampling. Adapun kriteria-kriteria yang ditentukan dalam penelitian ini, untuk tukang kiridit adalah: yang sudah merantau di Pekanbaru minimal tiga tahun; yang dianggap telah dan belum berhasil dalam bisnis kiridit; memiliki pelanggan sekurang-kurangnya berasal dari empat kelompok etnik yang berbeda; pernah merasa ditipu oleh pelanggan; dan memiliki wilayah perdagangan di dalam kota Pekanbaru. Dalam penelitian ini informan tukang kiridit sebanyak tiga belas orang, dan informan pelanggan sebanyak enam orang. Sedangkan teknik pengambilan informan ditentukan dengan menggunakan teknik bola salju (snowball sample unit) yang dimulai dari informan awal (pangkal) atau disebut juga sebagai gate keeper. Untuk penarikan informan pelanggan dilakukan dengan kriteria mewakili empat kelompok etnik mayoritas yang menjadi pelanggan kiridit yakni, etnik Minang, Melayu, Jawa, Batak, ditambah pelanggan dari etnik Sunda sendiri. Penentuan informan pelanggan didasarkan pada informasi dari tukang kiridit informan sendiri.

Penelitian ini dilaksanakan di Kota Pekanbaru Provinsi Riau dengan pertimbangan: (1) Sistem kiridit di Kota Pekanbaru berbeda dengan di tempat lain yaitu tidak ada istilah bos berantai, tetapi hanya megenal satu bos; (2) Adanya perbedaan budaya (bahasa, etnik, dan adat istiadat) antara tukang kiridit dengan mas- yarakat Pekanbaru yang menjadi pelanggannya; dan (3) Para tukang kiridit yang ada di kota Pekanbaru terorganisisir dengan baik dalam suatu paguyuban bina usaha kiridit yang dinamakan 'binangkit' yang bernaung di bawah Yayasan 'Misuri' (Mitra Sunda Riau).

Untuk memperoleh data yang dibutuhkan dalam penelitian ini, peneliti menggunakan tiga teknik pengumpulan data, yaitu: pengamatan (observasi), wawancara mendalam, dan studi dokumentasi. Prosedur analisis data yang digunakan dalam penelitian ini meliputi: mengumpulkan informasi dari lapangan, menyortir informasi menjadi kelompok-kelompok, memformat informasi ke dalam sebuah cerita, dan menulis naskah kualitatif. Semua kegiatan ini dilakukan secara bersamaan (Creswell, 1994: 153).

Adapun model analisis data yang dipakai adalah model interaktif, yaitu bahwa komponen-komponen analisis data (yang mencakup reduksi, penyajian data, dan penarikan kesimpulan) secara interaktif saling berhubungan selama dan sesudah pengumpulan data. Untuk teknik pemeriksaan keabsahan data, peneliti mengikuti pendapat Agus Salim (2006: 20) yang menyebutkan adanya empat konsepsi validitas dalam penelitian kualitatif, yaitu: validitas kumulatif, validitas komunikatif, validitas argumentatif, dan validitas ekologis.

\section{HASIL DAN PEMBAHASAN}

Ketiga belas orang tukang kiridit yang menjadi informan dalam penelitian ini mengatakan bahwa mereka awalnya bisa menjadi tukang kiridit karena ikut atau diajak seseorang. Perbedaan terdapat hanya pada siapa orang yang mengajak atau yang diikutinya, yaitu ada yang diajak oleh saudara atau masih kerabat dan ada yang diajak oleh orang lain yang tidak memiliki hubungan saudara, misalnya

teman. Dari ketiga belas informan, sepuluh orang di antaranya menjadi tukang kiridit karena awalnya diajak oleh saudara, yang peneliti sebut milu dulur, dan hanya tiga orang yang penyebabnya karena diajak teman yang peneliti sebut milu batur.

Milu dulur artinya ikut saudara dan milu batur artinya ikut orang lain. Penggunaan kata milu dalam kategori disini untuk menunjuk- 
kan bahwa informan tukang kiridit aktif untuk mengikuti orang. Berbeda jika menggunakan kata diajak yang lebih cenderung mengandung arti bahwa informan tersebut pasif. Hal ini didasarkan kepada pernyataan informan sendiri yang rata-rata mengaku sudah mempunyai niat sendiri menjadi tukang kiridit walaupun awalnya diajak oleh orang lain. Berikut ini akan dijelaskan secara lebih rinci dari kedua kategori tukang kiridit tersebut.

Sudah menjadi tradisi tukang kiridit apabila merantau ke tempat lain dan kalau sudah dapat dibilang sukses, biasanya mereka akan mengajak saudaranya untuk sama-sama merantau mengembangkan usahanya. Orang yang diajak ini pada awalnya hanya membantu seniornya misalnya untuk menjadi pembawa barang atau pananggung. Proses ini sering juga disebut dengan proses bubujang (membantu). Apabila dianggap sudah paham, baik terhadap sistem kiridit maupun terhadap daerah atau wilayah $i d-$ eran (wilayah perdagangan), maka secara perlahan tukang kiridit 'yunior' ini mulai disuruh mandiri dan diberi seniornya. Modal awal biasanya diperoleh dari pembagian atas hasil proses bubujang bersama majikannya. Sistem pembagiannya menggunakan sistem paro, yaitu jumlah uang yang ada "diluar" (yang belum ter- kutip atau tertagih) dibagi dua dengan sang majikan. Dengan modal uang itulah tukang kiridit yunior ini melanjutkan usahanya secara mandiri. Biasanya proses bubujang ini memakan waktu selama kurang lebih tiga tahun.

Hubungan saudara atau dulur dengan orang yang diikuti oleh tukang kiridit pemula ini bervariasi, ada yang mengikuti kakak kandung, kakak ipar, ada yang diajak oleh paman, dan ada juga karena ikut suami. Karena informan yang ikut suami hanya satu orang, maka peneliti masukkan ke dalam kelompok atau kategori milu dulur walaupun sebenarnya suami tidak termasuk dulur.

Berbeda dengan tukang kiridit milu dulur, yang mayoritas menjadi tukang kiridit sebagai pekerjaan mereka yang utama, tukang kiridit milu batur ini menjadikan profesi tukang kiridit sebagai alternatif pekerjaan pengganti dari profesi sebelumnya yang dirasakan kurang tepat atau kurang menjanjikan. Misalnya, Asep sebelum menjadi tukang kiridit adalah sebagai sopir, Deden sebelumnya sebagai penjual gorden, dan Dudus pernah bekerja di salah satu pabrik di Jakarta.

Proses menjadi tukang kiridit berikut motif atau alasannya dapat digambarkan secara skematis seperti di bawah ini:

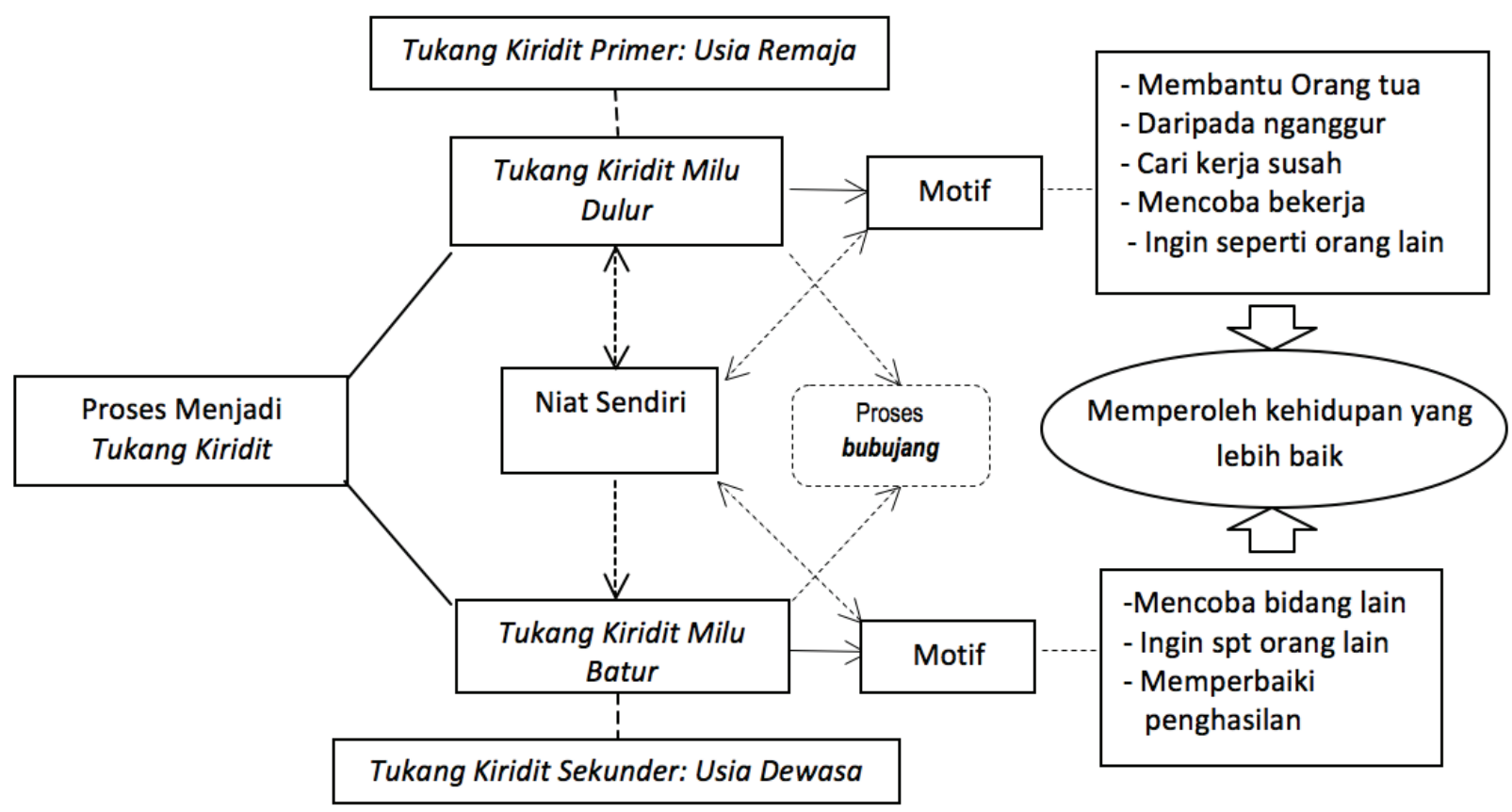

Gambar 1 Model Proses Menjadi Tukang Kiridit 
Konsep diri merupakan suatu kajian yang penting dalam teori interaksi simbolik. Konsep diri adalah pandangan individu mengenai dirinya yang akan mempengaruhi tindakan dan perilaku tersebut. Seperti telah diuraikan dalam hasil penelitian sebelumnya bahwa konsep diri individu sangat tergantung pada pandangan orang lain terhadap individu tersebut. Sebagai contoh, pandangan tukang kiridit terhadap diri dan profesinya, ditentukan oleh pandangan orang lain terhadap tukang kiridit itu sendiri yang dia temukan dalam interaksi sosial. Tidak semua pandangan orang lain dapat mempengaruhi konsep diri, tetapi orang lain yang mempengaruhi konsep diri tukang kiridit ini adalah orang yang termasuk atau dikategorikan sangat penting atau dekat dalam kehidupan tukang kiridit, yaitu di antaranya adalah pelanggan.

Pandangan orang tua ternyata juga sangat berpengaruh terhadap konsep diri dan perilaku tukang kiridit. Beberapa informan mengatakan kalau dalam menjalankan bisnis kiridit ini selalu mengingat nasihat orang tua yang mewanti-wanti jangan sampai menyimpang dari papagon (aturan) agama. Orang tua adalah orang yang paling dekat dengan kita dan orang yang paling menyayangi kita di dunia ini. Tidak cukup ketika kita kecil saja selama dalam asuhannya, sampai dewasa pun kasih sayang orang tua tidak akan pernah pudar. Ini yang dirasakan tukang kiridit, meskipun sudah berkeluarga dan hidup mandiri, tetapi perhatian orang tua tetap sangat besar. Perhatian ini diwujudkan dalam nasihat-nasihat dan kekhawatirannya kalau-kalau usaha anaknya ini dilakukan dengan cara yang tidak baik. Informan mengaku sering ditanya orang tuanya dari mana bisa membeli ini dan itu, apakah rezeki tersebut diperoleh dengan cara yang benar atau tidak. Inilah salah satu bentuk kasih sayang orang tua, mereka tidak serta merta merasa bangga ketika anaknya mampu mengumpulkan kekayaan, sebelum mengetahui dengan pasti dari mana dan dengan cara bagaimana kekayaan itu diperolehnya.

Selain orang-orang yang paling dekat dan dianggap penting oleh tukang kiridit, kelompok rujukan juga mempunyai peranan yang sangat penting di dalam konsep diri tukang kiridit. Kelompok rujukan bagi tukang kiridit, tidak hanya berupa kelompok paguyuban profesi, tetapi lebih besar dan universal seperti kelompok et- nik dan norma-norma keagamaan yang mereka anut. Meskipun hidup di perantauan dan jauh dari kampung halaman, bahkan dalam rentang waktu yang sudah cukup lama, sebagai bagian dari kelompok etnik Sunda tukang kiridit tetap terikat oleh identitas kesundaannya. Sikap 'nyunda' tukang kiridit ini terpantul dari perilaku mereka yang tetap handap asor, someah dan darehdeh. Rendah hati, santun, dan ramah. Gambaran ini tidak hanya terlihat sewaktu peneliti melakukan observasi saja, tetapi juga berdasarkan pengakuan para pelanggan.

Sebagai proses sosial, dalam komunikasi interpersonal tukang kiridit melibatkan pihak lain terutama dalam hal ini yaitu para pelanggan. Komunikasi yang terjalin antara tukang kiridit di satu pihak dengan pelanggannya di pihak lain merupakan suatu bentuk komunikasi interpersonal yang berimplikasikan komunikasi antarbudaya karena terjadi di antara dua subkultur yang berbeda.

Bukan saja karena perbedaan profesi tetapi juga bisa berbeda etnik atau suku. Dalam konteks transaksi penjualan, tukang kiridit bisa menjadi orang (aktor) yang memulai proses komunikasi (ketika mereka menawarkan barang) tetapi bisa juga pelanggan yang memulainya ketika pelanggan memesan suatu barang.

Secara skematik dapat digambarkan model komunikasi interpersonal tukang kiridit di halaman berikut:

Berdasarkan hasil wawancara dengan tukang kiridit informan ternyata bahwa seluruh informan pernah mengalami 'dikhianati' pelanggannya. Bentuk pengkhianatan ini pada umumnya dengan cara ditinggal kabur pelanggan pada masa kiriditan belum lunas. Pelanggan yang kabur ini alasannya karena pindah rumah sewaan, pulang kampung dan karena tidak jualan lagi (khusus pelanggan yang berjualan di pasar). Ada pula pelanggan 'nakal' yang pada awalnya menjadi pelanggan yang baik (biasanya ketika membeli barang-barang yang kecil), tetapi lama kelamaan kepercayaan tukang kiridit kepadanya kemudian disalahgunakan untuk tujuan membeli barang-barang mahal yang akhirnya 'kabur' pada saat-saat awal masa angsuran kredit.

Berbekal pengalaman pahit dikhianati pelanggan seperti yang diuraikan di atas, maka tukang kiridit melakukan upaya mengkonstruksi trust terhadap pelanggan dengan berbagai cara. 


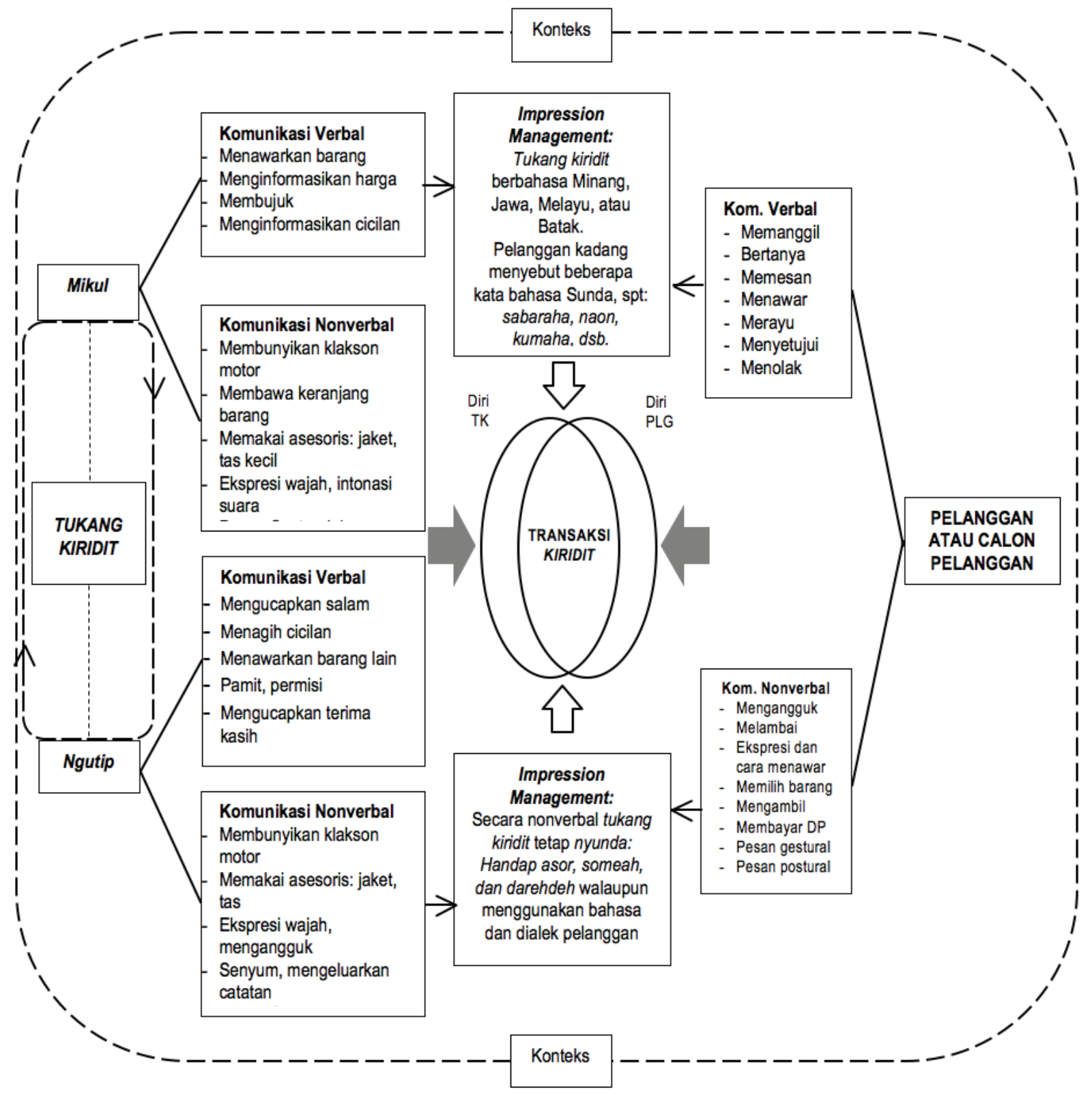

Gambar 2 Model Proses Komunikasi Interpersonal tukang kiridit dengan pelanggannya.

Ada informan yang menandai calon pelanggan yang tidak bisa dipercaya dilihat dari cara dia menawar barang. Kalau calon pelanggan terlalu ambisius untuk membeli barang tanpa mempedulikan harga yang ditawarkan sangat tinggi, biasanya calon pelanggan seperti ini ada maksud terselubung yang kurang baik. Sebaliknya kalau calon pelanggan menawar harga dengan ketat dan ngeyel, biasanya calon pelanggan seperti ini relatif lebih dapat dipercaya. Informan lain mengatakan bahwa pelanggan yang tidak baik bisa dikenali dari cara dia memesan barang. Kalau memesan barang sekaligus dalam jumlah yang banyak (hayang sagala dibeuli) biasanya itu pertanda yang kurang baik.
Ada juga informan yang menandai calon pelanggan yang 'nakal' dari gerak geriknya. Tetapi ada juga informan yang menurutnya feeling dialah yang dapat mendeteksi sifat calon pelangganya. Bahkan ada informan yang menggunakan istilah kereteg hate atau suara hati sebagai alat untuk mengkonstruksi trust kepada pelanggannya.

Dari konstruksi trust terhadap pelanggan yang dilakukan tukang kiridit, pada umumnya informan menjadikan bentuk komunikasi nonverbal pelanggan dijadikan sarana utama penilaian tentang dapat tidaknya mereka dipercaya. Komunikasi nonverbal ini meliputi gestur, paralinguistik, ekspresi wajah, dan sebagainya. 
Sedangkan komunikasi verbal sangat sulit dipedomani karena ketika proses transaksi kiridit tidak ada suatu perjanjian tertentu yang mengarah kepada trust itu sendiri yang dilakukan secara verbal, kecuali adanya suatu kesepakatan (tidak tertulis). Kesepakatan yang dibangun ketika transaski hanya berkisar pada besaran harga, besaran angsuran, ketentuan uang muka, serta periode angsuran.

Dalam menghadapi calon pelanggan yang diduga tidak akan baleg (Bahasa Sunda, baleg = baik, benar, jujur), informan umumnya mempunyai trik yang sama yakni berpura-pura dengan mengatakan kepada calon pelanggan bahwa barang yang dipesan sedang kosong, atau persediaan di toko habis. Ini adalah suatu cara yang dianggap tidak akan menyinggung calon pelanggan. Sedangkan apabila kebetulan tukang kiridit sedang membawa barang yang dimaksud (istilah tukang kiridit disebut sedang mikul), maka dia akan berdalih bahwa barang tersebut merupakan pesanan orang atau sudah dipesan pelanggan lain.

Apapun cara dan teknik yang digunakan oleh para tukang kiridit dalam mengkonstruksi trust terhadap pelanggannya, ini menunjukkan bahwa tukang kiridit merupakan subjek yang secara aktif berupaya menghadapi berbagai risiko bisnis yang digelutinya sekaligus membuat solusi pemecahannya. Kerugian dari 'pengkhianatan' pelanggan ini bagi sebagian tukang kiridit memang tidak besar pengaruhnya karena pelanggan yang baik jauh lebih banyak jumlahnya. Tetapi bagi sebagian tukang kiridit yang bermodal tipis, ini menjadi masalah besar dan serius. Tidak sedikit tukang kiridit di Pekanbaru yang beralih profesi karena masalah ini. Misalnya ada yang beralih menjadi penjual kerupuk, bakso colok, siomay dan lain-lain.

Meskipun mengkonstruksi trust terhadap pelanggan sangat penting dalam rangka mengantisipasi sikap, perilaku, dan kredibilitas pelanggan, tetapi masih ada beberapa tukang kiridit yang masih 'lugu' dalam arti mereka selalu mempercayai dan berprasangka baik terhadap semua pelanggan, kendati mereka sendiri sering dikhianati. Bagi tukang kiridit seperti ini, selama dia mampu memenuhi pesanan pelanggan, dia akan memenuhinya seolah tidak peduli terhadap risiko yang akan terjadi. Dari temuan tersebut, maka dapat dibuat dua katogori tukang kiridit di dalam mengkosntruksi trust terhadap pelanggannya, yaitu: 1. Tukang kiridit aktif: konstruktif dan antisipatif; dan 2. Tukang kiridit'pasif': haarga diri positif. Model konstruksi trust oleh tukang kiridit terhadap pelanggannya dapat digambarkan pada gambar 3 di halaman berikut.

\section{SIMPULAN}

Berdasarkan paparan yang telah dijelaskan dalam hasil penelitian dan pembahasan, maka dapat ditarik beberapa simpulan sebagai berikut: (1) Proses tukang kiridit menjadi tukang kiridit umumnya diawali dengan mengikuti orang lain atau diajak orang lain. Kategori orang lain ini terbagi dua, yaitu ada yang masih memiliki hubungan keluarga atau saudara, dan ada yang tidak memiliki hubungan saudara. Kategori pertama melahirkan istilah tukang kiridit milu dulur (tukang kiridit ikut saudara), dan yang kedua melahirkan tukang kiridit milu batur (tukang kiridit ikut orang lain); (2) Konsep diri atau pandangan tukang kiridit terhadap dirinya pada umumnya sangat positif, dalam arti mereka merasakan enak, bangga, bahkan ada yang mengatakan mulia menjadi tukang kiridit.

Sampai saat penelitian ini dilakukan, tidak satu pun dari informan yang punya pikiran untuk beralih profesi. Mereka yang mengatakan enak dan bangga didasari oleh keberhasilannya secara ekonomi dan mereka bisa menikmati hasil jerih payahnya menjadi tukang kiridit pada usia yang relatif masih muda. Adapun yang mengatakan tukang kiridit sebagai profesi yang sangat mulia didasarkan pada persepsi dirinya yang merasa banyak membantu orang lain terutama masyarakat kelas ekonomi lemah yang tidak mampu membeli kebutuhan rumah tangganya secara tunai; (3) Proses komunikasi interpersonal antara tukang kiridit dengan pelanggannya diwarnai pengelolaan kesan (impression management) yang dilakukan oleh kedua belah pihak. Bagi tukang kiridit ini merupakan salah satu taktik untuk memperoleh tujuannya mengambil hati calon pelanggan. Pengelolaan kesan dilakukan secara verbal dan nonverbal, mulai dari menggunakan bahasa sesuai dengan bahasa pelanggan atau pembeli berikut peniruan dialeknya. Pengelolaan kesan dengan melakukan kepura-puraan selalu dilakukan oleh $t u$ - 


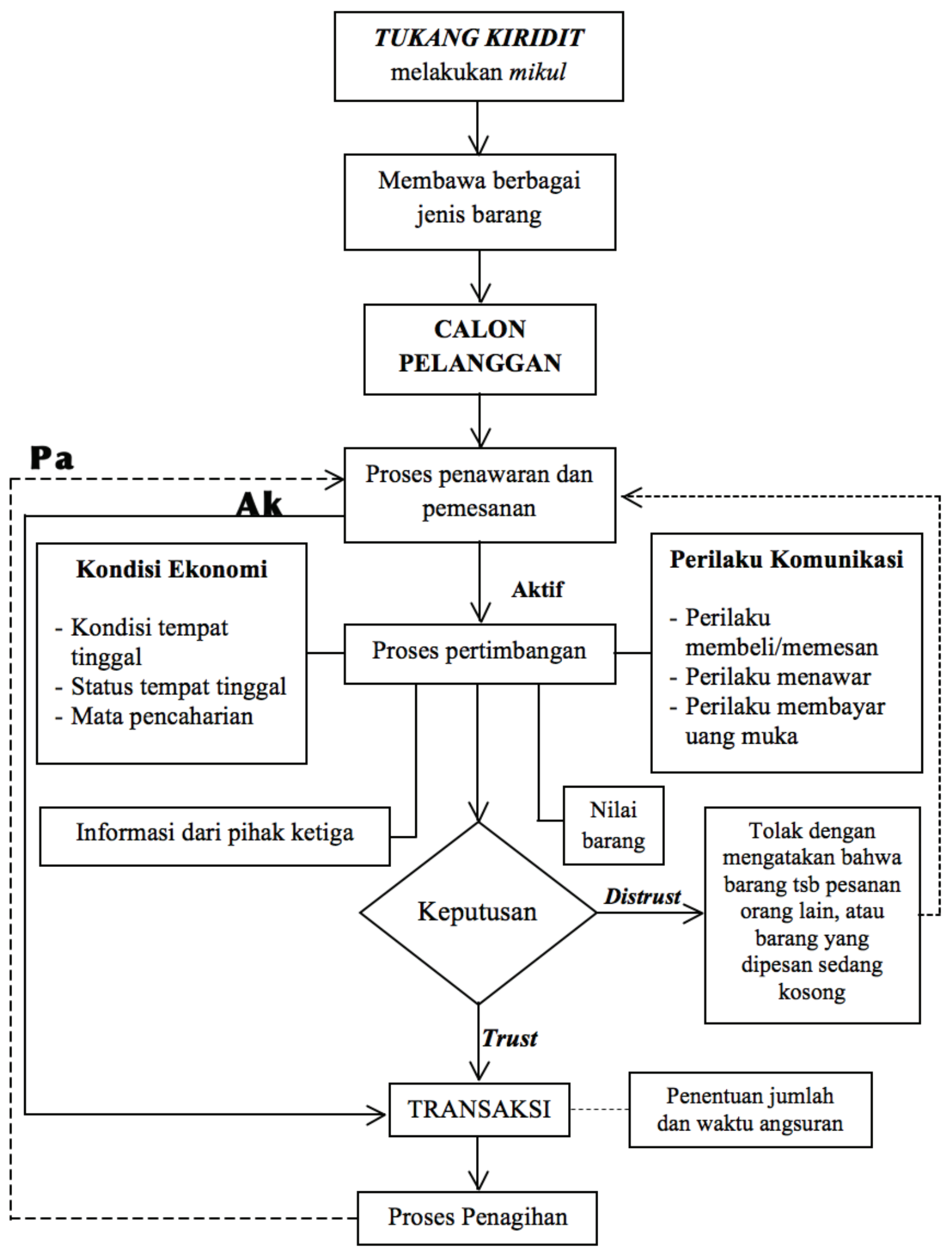


kang kiriditi, apalagi ketika berhadapan dengan calon pembeli yang dinilai kurang meyakinkan. Artinya apabila calon pembeli dipersepsi tidak dapat dipercaya, maka tukang kiriditakan berusaha menghindari orang tersebut dengan cara 'bersandiwara' atau berbohong. Misalnya dia mengatakan bahwa barang yang dipesan orang tersebut sedang kosong, tidak ada di pasar atau toko. Atau dia mengatakan bahwa barang yang diminati orang tersebut merupakan pesanan orang lain dan seterusnya. Tahapan-tahapan hubungan interpersonal tukang kiridit dengan pelanggannya diawali dengan survei wilayah (pra-interaksi), mikul (initiating), uji coba pelanggan (experimenting), pengintensifan hubungan dengan menambah barang kreditan (intensifying), sampai selesainya periode kredit; (4) Di dalam mengkostruksi trust terhadap pelanggannya, pertimbangan tukang kiridit lebih banyak didasarkan kepada faktor-faktor simbolik yang berupa pesan nonverbal seperti: cara pelanggan di dalam menawar barang, cara pelanggan memesan barang, cara pelanggan melakukan pembayaran DP (uang muka), dan gerak-gerik serta perilaku komunikasi pelanggan. Di samping itu, tukang kirirdit kadang-kadang juga mempertimbangkan kondisi ekonomi pelanggan berdasarkan pekerjaan atau mata pencahariannya (apakah punya pekerjaan tetap atau tidak), status mukim dan tempat tinggal pelanggan (sudah berapa lama pelanggan tinggal di tempat bermukim sekarang dan apakah tempat tinggal milik sendiri atau menyewa), dan mempertimbangkan informasi dari pihak ketiga (misalnya tetangga) tentang sifat dan karakter pelanggan. Khusus bagi pelanggan lama, maka pengalaman berlangganan sebelumnya-lah yang akan menjadi faktor utama di dalam menentukan trust terhadap pelanggannya.

Berkaitan dengan temuan penelitian di lapangan, maka di bawah ini disampaikan saran-saran baik secara teoritis maupun praktis sebagai berikut:

Saran Teoritis: (1) Penelitian mengenai interaksi atau komunikasi antara pedagang dan pembeli sebaiknya ditindak lanjuti dengan penelitian serupa dengan menggunakan metode dan pendekatan yang berbeda. Untuk metode kualitatif, penelitian tentang topik ini akan sangat menarik apabila dilengkapi dengan pendekatan dramaturgi untuk mendalami lebih lanjut bagaimana para aktor komunikasi melakukan transaksi jual beli dengan cara pertunjukan diri (presentation of self) yang merupakan suatu bentuk dari pengelolaan kesan (impression management); dan (2) Berhubung pelanggan tukang kiridit di Pekanbaru (mungkin juga di kota lain) terdiri dari berbagai etnik, maka akan menarik apabila ditindak lanjuti dengan penelitian komunikasi antarbudaya yang penekanannya pada perbedaan pola atau bentuk komunikasi (termasuk taktik-taktik) tukang kiridit dengan masing-masing etnik pelanggannya yang berbeda-beda.

Saran Praktis: (1) Adanya pemahaman sebagian subyek mengenai trust sebagai prasangka baik terhadap pelanggan, disarankan perlu adanya reorientasi pemahaman melalui bimbingan dan arahan kepada mereka, bahwa mengkonstruksi trust terhadap pelanggan tidak sama dengan berprasangka buruk kepada mereka tetapi merupakan upaya untuk berhati-hati dan waspada, karena hasil penelitian membuktikan bahwa seluruh informan dalam penelitian ini pernah mengalami "penghianatan"dari pelanggannya termasuk informan yang selalu mempunyai prasangka positif tersebut; (2) Kepada para tukang kiridit khususnya yang tergabung di dalam paguyuban 'Binangkit' sebaiknya membentuk koperasi yang difasilitasi oleh Misuri (Mitra Sunda Riau) dan instansi atau dinas terkait guna menghimpun dana yang dapat digulirkan kepada anggota untuk keperluan tambahan modal usaha dan keperluan lainnya, mengingat paguyuban sudah cukup solid, alangkah baiknya kalau kekompakkan paguyuban ini lebih diarahkan lagi kepada kegiatan yang dapat menunjang kesejahteraan para anggota; dan (3) Kepada pemerintah daerah setempat (Pemko Pekanbaru), seperti diharapkan oleh tukang kiridit sendiri, diharapkan memperhatikan para "wirausahawan" migran ini misalnya dengan memberikan penyuluhan atau sejenis pelatihan tentang kewirausahaan terutama yang berkaitan dengan usaha perkiriditan ini, mengingat keberadaan mereka (tukang kiridit) telah banyak berperan di dalam membantu penduduk kota Pekanbaru khususnya mereka dari kalangan kelas ekonomi lemah. 
DAFTAR PUSTAKA

Creswell, J. W. (1994). Qualitative inquiry and research design: choosing among five tradition. USA: Sage Publications Inc.

Rakhmat, J. (1999). Psikologi komunikasi. Edisi Revisi. Bandung: Remaja Rosdakarya.

Salim, A. (2006). Teori \& paradigma peneli- tian sosial, buku sumber untuk penelitian kualitatif. Edisi Kedua. Yogyakarta: Tiara Wacana.

West, R. \& Lynn H. T. (2008). Pengantar teori komunikasi; analisis dan aplikasi. Edisi 3. Terjemahan Maria Natalia Damayanti Maer. Jakarta: Salemba Humanika. 